\title{
Development of a Complex Treatment Process for Recycling Household Laundry Water
}

\author{
Orsolya KELEMEN, ${ }^{1}$ Ildikó BODNÁR, ${ }^{2}$ Andrea IZBÉKINÉ SZABOLCSIK ${ }^{3}$ \\ University of Debrecen, Faculty of Engineering, Department of Environmental Engineering, Hungary \\ ${ }^{1}$ kelemen727@gmail.com \\ ${ }^{2}$ bodnari@eng.unideb.hu \\ 3szabolcsikandi@eng.unideb.hu
}

\begin{abstract}
The goal of our research is to study the treatment possibilities of the laundry water fraction of domestic greywater as an alternative water source, as well as to apply a complex treatment method with which we obtain purified greywater. This treated water can be used during household tasks that do not require drinking water. By optimizing each treatment step, we determined a complex process with the following steps: coagulation-quartz sand filtration-oxidation. We also investigated the usability of purified greywater for irrigation by performing a standardized seedling test and determining the SAR factor. In conclusion, based on the measured and analysed water analytical parameters, we have successfully applied an appropriate complex treatment method, using optimal amounts of chemicals, which according to international recommendations can be potentially reused at household level, and can also be used for irrigation purposes.
\end{abstract}

Keywords: greywater, laundry water, treatment, reuse, sustainability.

\section{Introduction}

Water is one of the factors that seriously affects our sustainable development. Today, however, more than one billion people do not have access to sufficient freshwater. One possible way to save water is to use so-called treated greywater for various household activities that do not require drinking water quality, such as toilet flushing, car washing or irrigation. Greywaters are fractions of used water from washing, bathing and laundering that do not come into contact with the water generated during toilet flushing. The washing fraction highlighted in our research contains a high concentration of detergents, chemicals, bleach, clothing dyes, oil and non-degradable tissues from detergents, e.g. from the clothes [1].

During the washing processes, the so-called surfactants and detergents are used, so there is a large amount of such substances in the greywater, which can be discharged into surface waters with the domestic wastewater. Here, by forming a thin layer of foam on the surface of the water, the amount of oxygen absorbed by the water and the efficiency of the self-cleaning process decrease, and algal blooms can start. Therefore, it is important to clean the wastewater from these surfactants and other contaminants before reuse. At present, there is no public health regulation for the reuse of greywater in Hungary.

In the United States, however, e.g. in 2012, the EPA (Environmental Protection Agency) issued a guide on the reuse of greywater. Among the qualification parameters, two parameters highlighted from this regulation: the value of the biological oxygen demand (BOD5), which is $10 \mathrm{mgL}^{-1}$, and the turbidity, which is recommended to be maximized at 2 NTU, as a condition for reuse [2]. Thus, we paid special attention to these parameters during the development of the treatment procedures.

\section{Synthetic greywater}

In order to compare the purification efficiency of the greywater treatment solutions, a constant 
composition tap water-based synthetic laundry water was prepared, which qualitatively represents the real greywater fraction from laundering. The composition of the real samples is very variable, so in order to monitor the correct treatment efficiencies, it is necessary to have a constant composition of the water to be treated. The starting raw water was developed synthetically according to a given recipe and later provided for the tests. In the production of synthetic laundry water, the quality parameters determined during the previous research of the Department of Environmental Engineering served as a guideline for the quality parameters to be achieved $[3,4]$. The constituent components of the samples were detergent and fabric softener, as well as vegetable oil and organic nutrients of natural origin to represent the contaminants.

We also examined the effect of the treatment on the increasingly popular so-called biodetergents. Instead of conventional detergents and fabric softener, liquid washing nuts and plant and mineral based fabric softener components were used in the sampling of "bio" laundry waters. As a qualification step, the $\mathrm{pH}$, turbidity, specific electrical conductivity, zeta potential, biological oxygen demand values, dissolved organic carbon content and chemical oxygen demand values of the samples were examined in parallel measurements.

\subsection{Determination of ANA-detergent content}

In addition to the continuous measurement of the water analytical parameters presented above, a special non-specific parameter was also measured between the individual treatment phases in order to check the effectiveness of the treatment step. This is the so-called anionic detergent (ANA) content. As the detergents found in real and synthetic laundry waters mainly contain anionic detergents, it is worth determining the anionic detergent content of the untreated laundry water sample and then monitoring the development of this summation parameter during the complex treatment process.

The method for quantifying the anionic detergent is a two-phase titration, which is a very simple and fast method of determination with relatively little equipment and chemical requirements. The measurement method used was based on ISO 2271: 1989 standard [5].

\section{The complex treatment process}

During the gradual application of the different greywater treatment methods, their effect on the greywater samples containing conventional and biodetergents was investigated, and then a complex treatment procedure was developed by optimally combining the steps. The operations of this process are coagulation, filtration and oxidation.

\subsection{Coagulation}

In connection with the chemical treatment processes, as a first step in the case of coagulation, the optimal amount of the iron(III)-chloride coagulant used for both types of samples was determined.

During the coagulation experiments, the coagulant was added to the greywater sample at various concentrations while continuously measuring the $\mathrm{pH}$, turbidity and zeta potential values of the water samples. These water quality indicators helped to determine the optimal amount of chemical. The optimal dose for conventional laundry water was $46-60 \mathrm{mg} \mathrm{FeCl}$, while for the biosynthetic sample this amount was 33.78-34.78 $\mathrm{mg} \mathrm{FeCl} \mathrm{F}_{3}$ per $100 \mathrm{~mL}$ sample. From these values, it can be clearly seen that the use of up to $42 \%$ less chemicals with the use of biodetergents may be sufficient for optimal treatment.

The characteristic parameters of the samples treated with the optimal dose are illustrated in Table 1.

Table 1. Effect of coagulation with optimal dose of $\mathrm{FeCl}_{3}$ on laundry water samples.

\begin{tabular}{|l|r|r|r|c|}
\hline Laundry water samples & $\begin{array}{c}\text { Syntetic laundry } \\
\text { water }\end{array}$ & $\begin{array}{c}\text { Coagulated syntetic } \\
\text { laundry water }\end{array}$ & $\begin{array}{c}\text { Biosyntetic laundry } \\
\text { water }\end{array}$ & $\begin{array}{c}\text { Coagulated biosyn- } \\
\text { tetic laundry water }\end{array}$ \\
\hline pH & $7.783 \pm 0.170$ & $2.387 \pm 0.39$ & $7.82 \pm 0.15$ & $4.2 \pm 0.31$ \\
\hline EC [mS/cm] & $1.03 \pm 0.021$ & $5.80 \pm 2.49$ & $1.64 \pm 0.08$ & $1.72 \pm 0.45$ \\
\hline Zeta-potencial [mV] & $-33.93 \pm 0.351$ & $-2.47 \pm 0.77$ & $-37.88 \pm 2.11$ & $-3.08 \pm 5.25$ \\
\hline Turbidity [NTU] & $85.17 \pm 8.819$ & $395.61 \pm 137.24$ & $40.69 \pm 5.59$ & $443.17 \pm 60.71$ \\
\hline BOI $_{5}$ [mg/l] & $420 \pm 52.915$ & $76.67 \pm 2.88$ & $281.28 \pm 56.05$ & $65 \pm 13.23$ \\
\hline DOC [mg/l] & $255.19 \pm 20.73$ & $217.58 \pm 23.17$ & $149.06 \pm 40.03$ & $79.06 \pm 3.60$ \\
\hline
\end{tabular}


Upon addition of the optimal dose of chemical, the contaminants settle in the form of flakes with the coagulant, which facilitates the next treatment step, the filtration.

\subsection{Filtration with quartz sand layer}

After coagulation, during the filtration step, the samples were filtered through a quartz sand filter (Figure 1), which removed the contaminants formed into flakes with the coagulant with high efficiency (Figure 2), reducing the turbidity and organic matter content of the sample by this.

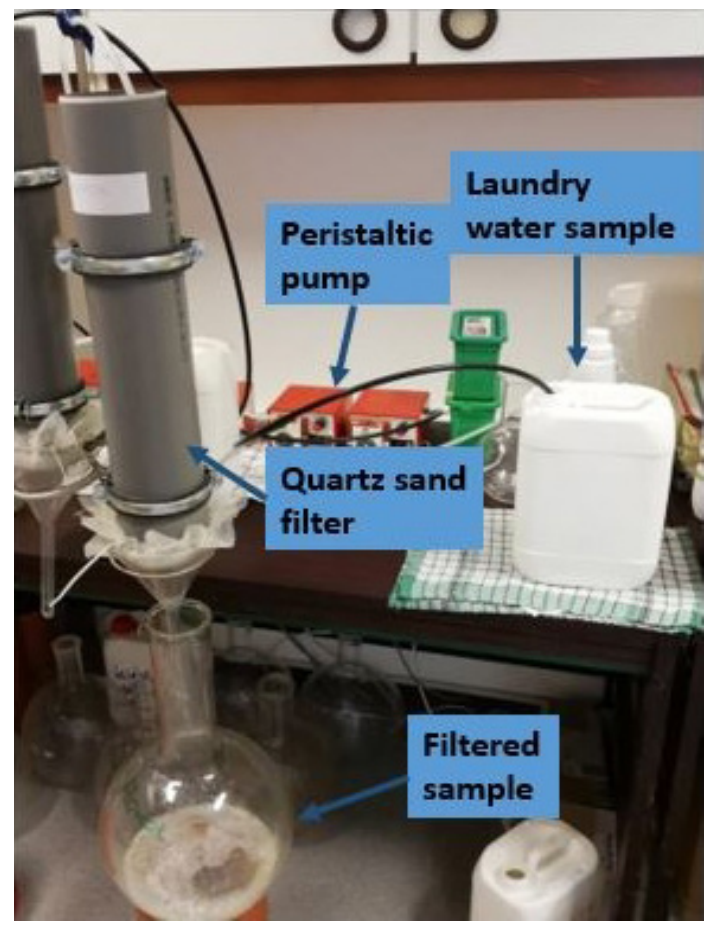

Figure 1. Structure of quartz sand filter.
However, the upper limit of the qualification parameters recommended in the international regulation - 2 NTU in case of turbidity and $10 \mathrm{mgL}^{-1}$ in case of biological oxygen demand - was not reached at that time. This can be seen from the values given in Table 2 .

\subsection{Oxidation}

In this step, the already coagulated and filtered sample was treated with $128 \mathrm{mmolL}^{-1}$ hydrogen peroxide by optimization, and after 1 hour, the quality characteristics of the oxidized sample

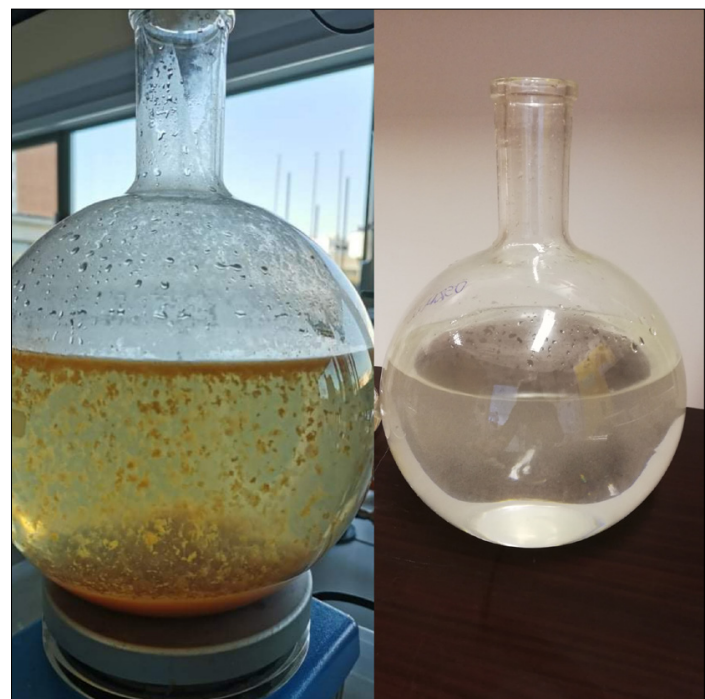

Figure 2. Post filtration (coagulated) and past filtration sample.

Figure 2. Effect of filtration on coagulated samples

\begin{tabular}{|l|r|r|r|c|}
\hline Laundry water samples & $\begin{array}{c}\text { Coagulated syntetic } \\
\text { laundry water }\end{array}$ & $\begin{array}{c}\text { Filtered syntetic } \\
\text { laundry water }\end{array}$ & $\begin{array}{c}\text { Coagulated biosyn- } \\
\text { tetic laundry water }\end{array}$ & $\begin{array}{c}\text { Filtered biosyntetic } \\
\text { laundry water }\end{array}$ \\
\hline pH & $2.387 \pm 0.39$ & $7.624 \pm 0.208$ & $4.2 \pm 0.31$ & $7.07 \pm 0.51$ \\
\hline EC [mS/cm] & $5.80 \pm 2.49$ & $1.94 \pm 0.12$ & $1.72 \pm 0.45$ & $1.41 \pm 0.38$ \\
\hline Zeta-potencial [mV] & $-2.47 \pm 0.77$ & $10.23 \pm 3.68$ & $-3.08 \pm 5.25$ & $-7.88 \pm 6.97$ \\
\hline Turbidity [NTU] & $395.61 \pm 137.24$ & $2.08 \pm 0.35$ & $443.17 \pm 60.71$ & $1.06 \pm 0.36$ \\
\hline BOI $_{5}$ [mg/l] & $76.67 \pm 2.88$ & $22 \pm 14.73$ & $65 \pm 13.23$ & $14 \pm 2.59$ \\
\hline DOC [mg/l] & $217.58 \pm 23.17$ & $35.34 \pm 9.39$ & $79.06 \pm 3.60$ & $28.49 \pm 10.07$ \\
\hline
\end{tabular}


were analysed. Based on the obtained results, values of less than 2 NTU for turbidity and less than $10 \mathrm{mgL}^{-1}$ for biological oxygen demand were obtained by the end of the oxidative treatment in accordance with international recommendations. The effect of oxidation can be seen from the values given in Table 3.

\section{Summary of the efficacy of a com- plex treatment procedure}

The quality of the synthetic laundry water purified during the applied treatment steps (coagulation-sand filtration-oxidation) clearly improved in terms of water quality parameters. Figures 3 and 4 illustrates the continuous reduction of biological oxygen demand and turbidity values highlighted in the international regulation during each treatment step. The biological oxygen demand shows a direct decrease, as a result of the complex treatment we clearly reached a value below $10 \mathrm{mg} / \mathrm{l}$ in accordance with the international qualification regulation.

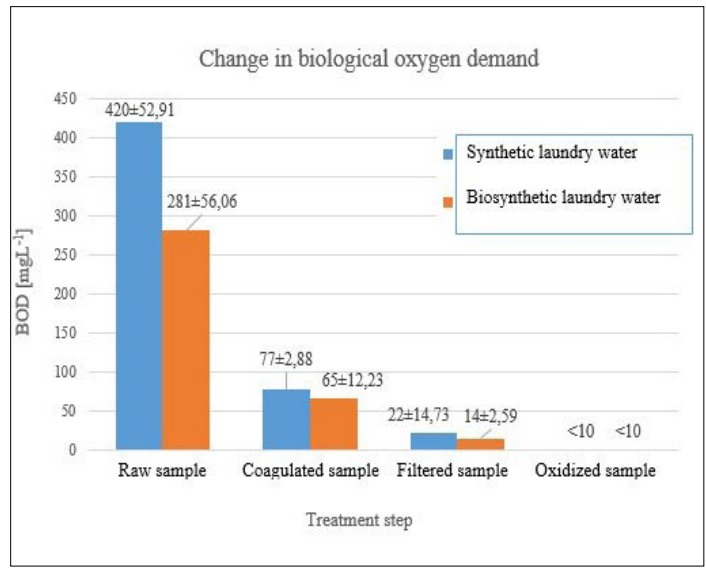

Figure 3. Reduction of biological oxygen demand during the steps of the complex treatment method.
In the case of turbidity, a significant increase in turbidity is observed during the coagulation step due to flocculation, but this decreases significantly after the subsequent filtration step, resulting in a values below the recommended 2 NTU by the end of the complex treatment method.

Furthermore, with regard to the measurement of the ANA detergent content, the results show that the complex treatment process effectively removes these components from the greywater. As shown in Figure 5, after the filtration step, the ANA detergent content is below the measurement limit.

\section{Seedling test}

A standardized seedling test was performed to investigate reusability for irrigation purposes [6]. In the seedling test, white mustard seeds were germinated for 72 hours. During the experiment, 25-25 untreated white mustard seeds of the same size and colour were placed at equal distances from each other in pre-sterilized and filter pa-

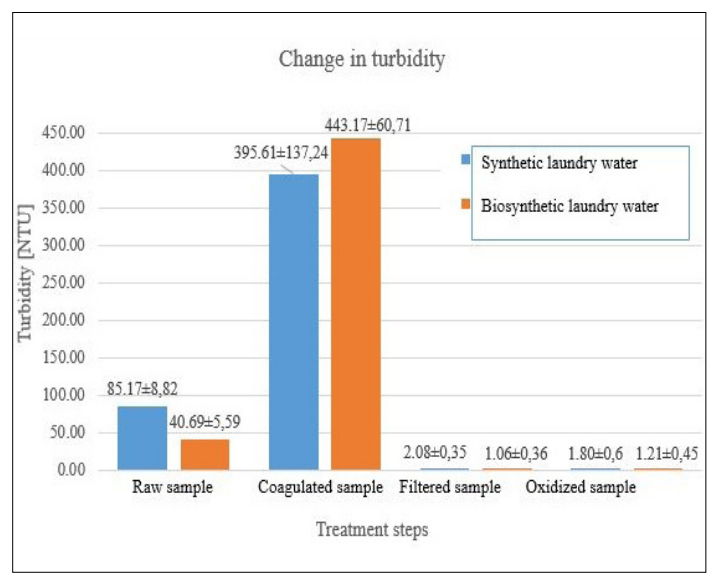

Figure 4. Change in turbidity during the steps of the complex treatment method.

Table 3. Efficiency of the oxidation treatment step

\begin{tabular}{|l|r|r|r|c|}
\hline Laundry water samples & $\begin{array}{c}\text { Filtered syntetic } \\
\text { laundry water }\end{array}$ & $\begin{array}{c}\text { Oxidized synthetic } \\
\text { laundry water }\end{array}$ & $\begin{array}{c}\text { Filtered biosynthe- } \\
\text { tic laundry water }\end{array}$ & $\begin{array}{c}\text { Oxidized biosynthe- } \\
\text { tic laundry water }\end{array}$ \\
\hline pH & $7.62 \pm 0.208$ & $7.73 \pm 0.13$ & $7.07 \pm 0.51$ & $7.07 \pm 0.44$ \\
\hline EC [mS/cm] & $1.94 \pm 0.12$ & $2.14 \pm 0.61$ & $1.41 \pm 0.38$ & $1.07 \pm 0.14$ \\
\hline Zeta-potencial [mV] & $10.23 \pm 3.68$ & $17.23 \pm 0.11$ & $-7.88 \pm 6.97$ & $-14.4 \pm 4.77$ \\
\hline Turbidity [NTU] & $2.08 \pm 0.35$ & $1.8 \pm 0.6$ & $1.06 \pm 0.36$ & $1.21 \pm 0.456$ \\
\hline BOI $_{5}$ [mg/l] & $22 \pm 14.73$ & $<10$ & $14 \pm 2.59$ & $<10$ \\
\hline DOC [mg/l] & $35.34 \pm 9.39$ & $21.08 \pm 2.36$ & $28.49 \pm 10.07$ & $26.11 \pm 11.03$ \\
\hline
\end{tabular}




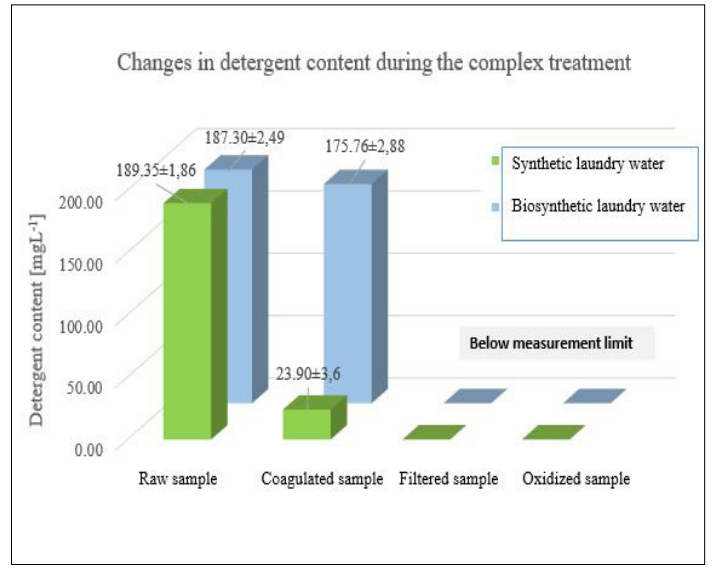

Figure 5. Change in ANA-content as a result of treatment.

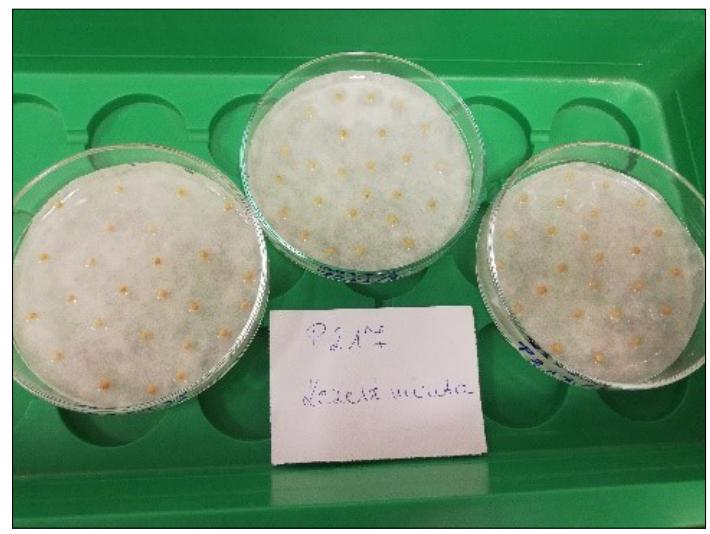

Figure 6. White mustard seeds.

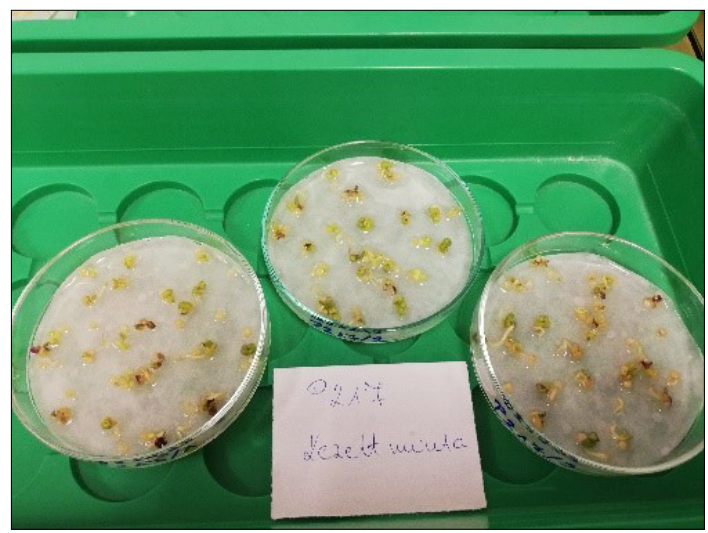

Figure 7. Seedlings.

per-lined petri dishes. The duration of the test was 72 hours, during which the petri dishes containing the seeds were kept in a germination box in a dark room at $20-22^{\circ} \mathrm{C}$.
3 parallel measurements were performed one at a time, using 3-3 petri dishes watered with tap water as control, untreated synthetic laundry water, and complex treated, purified synthetic laundry water. The experiment was performed with laundry water containing conventional as well as biodetergents.

The 6-7. Figures show the initial state of the seedling test for white mustard seeds as well as the final phase of the developed seedlings.

We examined in relation to seeds irrigated with drinking water:

- how many seeds had germinated;

- the extent of the growth (in terms of root and stem length);

- the biomass weight;

- the elemental composition of samples.

During the qualification, the first thing was to count how many seeds germinated from the 25 seeds per Petri dish.

Root and stem length measurements were performed individually for each germinated plant after 72 hours. Using the obtained data, we compared the quality indicators of irrigation waters. Wet and dry biomass weights were measured per Petri dish. Using the measured data, we calculated the moisture content of the seedlings belonging to different water samples, which provided a very good basis for comparing the differences between the irrigation water. In the case of the elemental composition test, the stem and root parts were analysed separately.

\subsection{Number of germinated seeds}

As shown in Table 4 . seeds irrigated with untreated laundry water have lower germination capacity than control tap water or treated laundry water. The treated samples show better germination ability in both conventional and bio laundry water.

\subsection{Root and stem length}

Germ growth was monitored by measuring root and stem length. The basis for comparison in this control was the size of the seedlings irrigated with drinking water. The values measured in millimetres were averaged, as shown in Table 5.

As expected, it was found that seedlings irrigated with the treated water had longer stem and root length than those that were irrigated with the untreated water. However, compared to tap water, there is also a lag in terms of growth during irrigation with treated samples. For root lengths, the difference was $60 \%$ smaller for germs irri- 
Table 4. Average of germinated seeds

\begin{tabular}{|l|c|c|}
\hline & Mean & Dev. \\
\hline Tap water & 23.33 & 0.58 \\
\hline $\begin{array}{l}\text { Untreated synthetic } \\
\text { laundry water }\end{array}$ & 19.00 & 1.00 \\
\hline $\begin{array}{l}\text { Treated synthetic } \\
\text { laundry water }\end{array}$ & 22.33 & 2.51 \\
\hline $\begin{array}{l}\text { Untreated biosynthe- } \\
\text { tic laundry water }\end{array}$ & 22.00 & 2.00 \\
\hline $\begin{array}{l}\text { Treated biosynthetic } \\
\text { laundry water }\end{array}$ & 23.67 & 1.53 \\
\hline
\end{tabular}

gated with conventional laundry water, while for germs irrigated with bio laundry water, this difference was $55 \%$. In the case of stem length we found a smaller difference from the germs irrigated with control tap water, in the case of irrigation with conventional laundry water the growth lag was $40 \%$, while in case of bio laundry water it was $2 \%$.

\subsection{Biomass weight and moisture content}

Biomass mass was measured in both wet and dry conditions. From these data, the moisture content of the plant germ parts was determined, from which the water absorption capacity of the samples could be deduced.

In almost all cases, lower values were measured compared to the control tap water irrigated germs, but the weight and moisture content of the treated water irrigated germs were higher than that of the untreated laundry water irrigated germs. Water uptake capacity is significantly affected by the detergent content of the irrigation water and the value of turbidity, as their deposition on plant parts can prevent water uptake. During germination, this was reflected in the fact that while seedlings irrigated with tap water and treated samples absorbed all irrigation water, seedlings irrigated with untreated laundry water usually retained water samples from previous irrigation. However, in the case of the treated sample, these confounding effects were largely eliminated. Furthermore, evaluating the data, it was found that the moisture content of the root was $10 \%$ higher than the moisture content of the stems. In conclusion, we deduced that moisture in plant germs may rather be stored in the root part.
Table 5. Root and stem length average

\begin{tabular}{|c|c|c|}
\hline Root $(\mathbf{m m})$ & $\begin{array}{c}\text { Synthetic } \\
\text { laundry water }\end{array}$ & $\begin{array}{c}\text { Biosynthetic } \\
\text { laundry water }\end{array}$ \\
\hline Tap water & $11.26 \pm 1.33$ & $15.84 \pm 2.03$ \\
\hline Untreated & $3.85 \pm 1.09$ & $6.37 \pm 0.29$ \\
\hline Treatted & $4.38 \pm 2.19$ & $7.24 \pm 0.62$ \\
\hline Stem (mm) & & \\
\hline Tap water & $14.62 \pm 4.62$ & $11.35 \pm 1.17$ \\
\hline Untreated & $7.65 \pm 0.09$ & $10.25 \pm 0.43$ \\
\hline Treatted & $8.82 \pm 0.34$ & $11.15 \pm 0.99$ \\
\hline
\end{tabular}

\subsection{Elemental analysis}

Elemental analysis of the seedlings of the germination experiment and the water samples used for their irrigation was performed using an Agilent 5110 ICP-OES instrument. 12 macro- and microelement measurements were performed on both plant samples and water samples.

In connection with the elemental analysis, the elemental content of the seedling was examined separately for the stem and root parts. Figure 8 . illustrates the microelement content of the stem portion.

It can be seen that iron, manganese and zinc are found in high concentrations in seedlings irrigated with laundry water, however, since these elements are present in similarly high concentrations in seedlings irrigated with tap water, this does not imply additional accumulation. Based on the obtained results, it can be said that the treatment of the laundry water is essential before the use for irrigation purposes, as the seeds irrigated

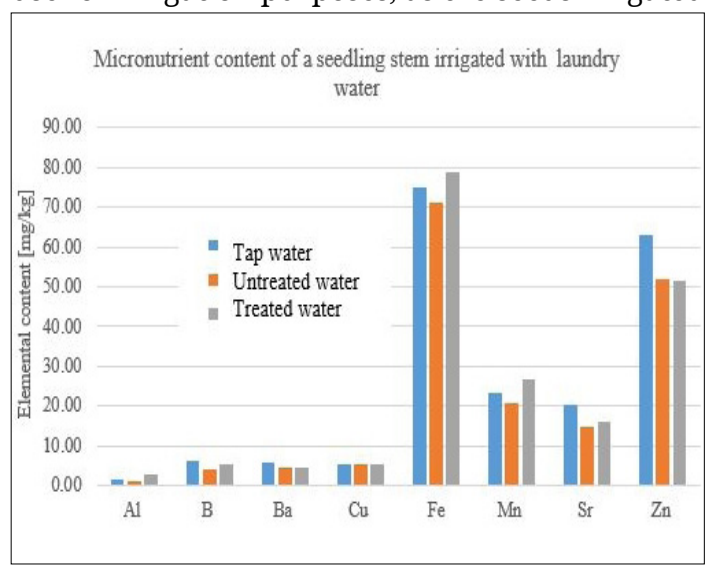

Figure 8. Seedling stem microelement content. 
with the untreated sample, both in the germination rate and in development, lagged behind the treated and tap water irrigated seeds.

\section{SAR-factor}

Based on an empirical formula available in the literature, the SAR value/factor shows the salinizing effect of water, e.g. irrigation water quality. Its salinization is important from the point of view that the salinity of the soil or irrigation water determines the fertility of the soil. In cases where the SAR value of the sample is between 2 and 4, the irrigation water does not endanger the fertility of the soil, while if the SAR value is highe, then the quality of the irrigation water can have a significant effect on the soil properties and the development of the plants [7].

This value is 2.38 for conventional laundry water and 2 for bio laundry water. This means that based on this parameter, the laundry water we treat in a complex process can be suitable for irrigation without compromising soil fertility.

\section{Conclusion}

In the preparation for reuse of the greywater from the laundering, coagulation, filtration on quartz sand filter and oxidation were used as treatment methods. Based on the measured and analysed water analytical parameters, we successfully applied an optimal treatment method using optimal amounts of chemicals. The parameters of the initial untreated and complex-treated samples are shown in Table 6-7.

Table 6. Effect of the treatment process on synthetic laundry water sample

\begin{tabular}{|l|c|c|}
\hline & $\begin{array}{c}\text { Untreated } \\
\text { synthetic } \\
\text { laundry } \\
\text { water }\end{array}$ & $\begin{array}{c}\text { Treated } \\
\text { synthetic } \\
\text { laundry } \\
\text { water }\end{array}$ \\
\hline pH & $7.783 \pm 0.170$ & $7.73 \pm 0.13$ \\
\hline EC [mS/cm] & $1.03 \pm 0.021$ & $2.14 \pm 0.61$ \\
\hline Zeta-potencial [mV] & $-33.93 \pm 0.351$ & $17.23 \pm 0.11$ \\
\hline Turbidity [NTU] & $85.17 \pm 8.819$ & $1.8 \pm 0.6$ \\
\hline BOI [mg/l] & $420 \pm 52.915$ & $<10$ \\
\hline DOC [mg/l] & $255.19 \pm 20.73$ & $21.08 \pm 2.36$ \\
\hline KOI [mg/l] & $1258 \pm 33.94$ & $1258.5 \pm 26.16$ \\
\hline ANA-detergent [mg/l] & $187.07 \pm 3.49$ & $<$ \\
\hline
\end{tabular}

As a result, by highlighting two of the qualification parameters in the international quality regulation, the biological oxygen demand (BOD5) value was reduced to $10 \mathrm{mgL}^{-1}$ and the turbidity below 2 NTU. Thus, at a household level, potentially reusable, purified greywater from washing was produced for tasks that do not require drinking water quality (toilet flushing, car washing, irrigation).

In connection with the performance of a seedling test, it can also be concluded that the complex-treated laundry water is potentially suitable for irrigation use and does not have a detrimental effect on soil fertility based on the SAR factor.

\section{References}

[1] Ghaitidak D. M., Yadav K. D.: Characteristics and Treatment of Greywater. A Review. Environmental Science and Pollution Research, 20/5. (2013) 2795-2809.

https://doi.org/10.1007/s11356-013-1533-0

[2] U.S. Environmental Protection Agency: Guidelines for Water Reuse. 2012.

[3] Bodnár I., Boros N., Baranyai E., Fórián S., Izbékiné Szabolcsik A., Jolánkái G., Keczánné Üveges A., Kocsis D.: Épületek csapadékvizeinek és szürkevizeinek vizsgálata az Észak-Alföld régióban környezetbarát és energiahatékony hasznositás céljából. In: Kalmár F. (szerk.): Fenntartható energetika megújuló energiaforrások optimalizált integrálásával. Akadémiai Kiadó, Budapest, 2014.

[4] Bodnar I., Szabolcsik A., Baranyai E., Uveges A., Boros N.: Qualitative Characterization of the Household Greywater in Northern Great Plain Region of Hungary. Environmental Engineering and Management Journal, 13/11. (2014) 2717-2724. https://doi.org/10.30638/eemj.2014.302

Table 7. Effect of the treatment process on biosynthetic laundry water sample

\begin{tabular}{|l|c|c|}
\hline & $\begin{array}{c}\text { Untreated } \\
\text { biosynthetic } \\
\text { laundry } \\
\text { water }\end{array}$ & $\begin{array}{c}\text { Treated } \\
\text { biosynthetic } \\
\text { laundry } \\
\text { water }\end{array}$ \\
\hline pH & $7.82 \pm 0.15$ & $7.07 \pm 0.44$ \\
\hline EC [mS/cm] & $1.64 \pm 0.08$ & $1.07 \pm 0.14$ \\
\hline Zeta-potencial [mV] & $-37.88 \pm 2.11$ & $-14.4 \pm 4.77$ \\
\hline Turbidity [NTU] & $40.69 \pm 5.59$ & $1.21 \pm 0.456$ \\
\hline BOI [mg/l] & $281.28 \pm 56.05$ & $<10$ \\
\hline DOC [mg/l] & $149.06 \pm 40.03$ & $26.11 \pm 11.03$ \\
\hline KOI [mg/l] & $1341 \pm 28.99$ & $909 \pm 2.83$ \\
\hline ANA-detergent [mg/l] & $189.95 \pm 2.14$ & $<$ \\
\hline
\end{tabular}


[5] ISO 2271:1989: Surface Active Agents - Detergents - Determination of Anionic-Active Matter by Manual or Mechanical Direct Two-Phase Titration Procedure.

[6] MSZ 22902-4: Víztoxikológiai vizsgálatok. Csíranövényteszt. 1991.

[7] Zsembeli J., Szűcs L.: Zöldségnövények környezetkímélő öntözése magas sótartalmú vizekkel. Agrártudományi Közlemények, 2014/61. 